\title{
THE DARK SIDE OF THE ALBANO CRATER LAKE
}

\author{
Marco Anzidei ${ }^{(1)}$, Alessandra Esposito ${ }^{(1)}$, Francesco De Giosa ${ }^{(2)}$ \\ Istituto Nazionale di Geofisica e Vulcanologia, Roma, Italy \\ Coastal Consulting and Exploration, Bari, Italy
}

\begin{abstract}
The Albano Lake is the deepest volcanic lake among the volcanoes located in the Italian peninsula. It belongs to the Colli Albani volcanic complex whose last largest eruptions are dated back to about 30 Kyr, although minor events likely occurred during historical times at $7000 \mathrm{yr}$ B.P. or earlier. After the end of the volcanic activity the Crater of Albano became a lake whose level changes are known since historical times. On November 2005, was performed the first very high resolution bathymetric survey of the Albano lake by means of a multibeam echo sounder, integrated with the GPS/RTK positioning technique A particular effort was devoted to produce a high resolution morphobathimetric map, which aims to provide a Digital Terrain Model of the lake floor for wide applications. The surveys did not revealed significant gas exhalative centres, which should indicate a current active gas release from the lake floor. Here we show the technical details of the bathymetric surveys, the very high resolution bathymetric map and the main morphological features of the Albano Lake bottom.
\end{abstract}

Key words: Alban Hills volcano, Albano Lake, multibeam bathymetry

\section{Introduction}

The Colli Albani volcanic complex occupies a wide area about $25 \mathrm{~km} \mathrm{SE}$ of Rome. Its general structure is a caldera with a central cone, although this complex displays two nested calderas and several more or less eccentric post-caldera vents, most of which produced by explosive activity. The highest point is Monte Cavo at $949 \mathrm{~m}$, which consists in a scoria cone located in an eccentric position on the SW rim of the younger Faete caldera. The two crater lakes of Albano and Nemi fill the most recent craters of the volcano (Fig.1).

The former geological studies performed by Fornaseri et al. (1963) and De Rita et al. (1988), dated all deposits of the Colli Albani at an age older than Holocene (>10,000 years) and until recent time, they have been considered an extinct volcano, although some historical documents reported some eruptive activity around 114 B.C. (Funiciello et al., 2002) and 7000 yr B.P. (Andretta and Voltaggio, 1988). In recent times, evidences of an ongoing volcanic unrest based on instrumental 
seismological and geodetic data, have been detected (Amato and Chiarabba 1995; Chiarabba et al. 1997; Anzidei et al. 1998), and new researches indicates that likely occurred an eruptive activity during the Holocene (Funiciello et al. 2003; Porreca et al. 2003), as also previously suggested by Andretta e Voltaggio (1998) and Villa et al. (1999).

Measurements of ground deformation available from high precision levelling lines established by IGM in 1951, as well as other benchmarks measured at the end of the last century, indicated un uplift at $30 \mathrm{~cm}$ in 43 years at a rate at $\sim 0.7 \mathrm{~mm} / \mathrm{yr}$ (Amato and Chiarabba, 1995) and the broad deformation zone evidenced through DinSAR observations by Salvi et al. (2004), mainly across the two lakes of Albano and Nemi, were interpreted as related to a superficial source (3-6 km), producing a signal similar to many active volcanoes (Amato and Chiarabba, 1995; Chiarabba et al., 1997; Salvi et al., 2004). Dangerous gas release have been observed from the ground in an area densely populated (Chiodini and Frondini 2001; Annunziatellis et al. 2003; Carapezza et al. 2003), is likely the result of fracturing produced during the seismicity of 1989-1990 and 1995, 1999 (Beaubien et al. 2003).

From regional tectonic evidences and long-term behaviour of the volcanic complex, Karner et al. (2001a, b) and Marra et al. (2003) estimated that the volcano could be at the beginning of a new eruptive phase. The existence of a potentially active volcano so close to the centre of Rome and other minor but not less important villages, all densely inhabited, is now leading scientists to revise the volcanic hazards of this area not only for the scenario of new eruptions but also for the recurrent seismicity that periodically strikes the volcano (Amato et al. 1994) and of the possibility of dangerous sudden gas release, rich in $\mathrm{CO}_{2}$, from the bottom of the lakes of Albano and Nemi, as in case of the catastrophic events occurred in the African crater lakes of Monoun (Sigurdsson et al., 1987) and Nyos (Barberi et al.1989; Rice, 2000).

The Albano Lake, also known as the Castelgandolfo Lake, is located at $293 \mathrm{~m}$ above sea level and it is the deepest among the volcanic crater lakes of Italy, being nowadays $167 \mathrm{~m}$ deep. Presently, it is $3.5 \mathrm{~km}$ long and $2.3 \mathrm{~km}$ wide with an extension of about $6 \mathrm{~km}^{2}$. It was settled since pre-historical times (Meli, 1911; Ryves et al., 1996; Manca et al., 1996; Lowe et al., 1996) and during the roman epoch became a place of greater importance (Carandini, 1997). In recent times, this nice and quiet place frequented by tourists, is the summer residence of the Pope at Castel Gandolfo village, located just on the top of the crate rim which contains the Albano Lake. Due to its frequent level changes (Marra and Karner, 2005), produced by deep water circulation and a likely catastrophic overspill, occurred in 398 B.C., induced the Romans to excavate an artificial outlet, to control lake level (Funiciello et al., 2002, 2003). 
Based on these data, under the umbrella of the Italian Dipartimento della Protezione Civile, was started a multi parametric study of the Colli Albani volcano, including a high resolution bathymetry of the groundfloor of the Lake of Albano, still not yet investigated by such surveys. This technique is capable to produce 2-D and 3-D images of the morphology of submerged volcanic areas, useful for wide applications, including hazard estimation (Anzidei, 2000; Anzidei et al., 2005; Esposito et al., 2006).

\section{Bathymetric surveys}

A multibeam high resolution survey that covered the whole area of the lake was performed for the first time in November, 2005, using the Alsea boat of Coastal Consulting and Exploration Company (Fig. 2), equipped with ultra high resolution multibeams and survey instrumentation (Fig.3). Particularly, due to the relevant depth of the lake, were used an ultra high resolution Reson Seabat 8125 multibeam (250 beams, $0.5^{\circ} \times 1.0$ sector coverage, $455 \mathrm{Khz}$ ) up to $80 \mathrm{~m}$ depth and a Reson Seabat 8101 multibeam (101 beams, $0.5^{\circ}$ x $0.5^{\circ}$ sector coverage, $455 \mathrm{Khz}$ ), in the depth range 80$167 \mathrm{~m}$, up to the deepest point of the lake (Tab.1).

Before starting the surveys, a check of the health of the GPS/RTK data link was performed trough the planned survey. The bathymetric datum was established by measuring the water level through some GPS measurements along the shore of the lake. The instrumental height of the zero level was referred to a WGS84 geodetic benchmark (named ALBA) previously set up close to the lake (Fig.1; Tab.2). The latter was measured by geodetic space techniques using a couple of dual frequency GPS receivers, with reference to the GPS geodetic monument of INGR, located at INGV in Rome (Fig.1), which belongs to the National GPS network of the INGV, whose 3-D coordinates are known at a few mm level (Anzidei et al., 1998; Serpelloni et al., 2005). Elevation data of lake floor were thus given into the WGS84 reference system (ellipsoidal heights) because the reference benchmark ALBA was not linked to any levelling line and the hortometric elevation were not available for this benchmark.

The centimetric positioning of the vessel was computed by GPS technique in RTK mode during surveys. Real time coordinates were obtained by installing an Ashtech Aquarius reference station located on the GPS station ALBA and transmitting the differential corrections by a High Frequency link at $1 \mathrm{~Hz}$ rate to the mobile Aquarius GPS receiver, placed on board of the vessel. In addition to this, a Sg-Brown Meridian Surveyor gyrocompass, a Tss DM505 MRU and a Fugro Omnistar Differential GPS, were interfaced to the Reson PDS2000 Navigation software for data acquisition (multibeam and positioning), control, calibration and pre-processing. An SBE 37-SI Microcat CTD probe was located at the sonar head and interfaced to the sonar processor, providing the real time speed of sound data for the beam forming, whereas the Navitronics SVP15 and a SeaBird CTD 
probes were also used for profiling the temperature, conductibility and the speed of sound along the water column (Fig.6). Additional details on the employed instrumentation are reported in Table 1. Navigation routes (Fig.4) were performed in order to achieve the full coverage of the lake bottom, with at least 20-30\% overlap of the nearby swaths. The Reson PDS2000 software was able to show in real time to the operator and the pilot the ongoing multibeam and Digital Terrain Model (DTM) and the positioning information that were used for guidance.

At the beginning of each survey, a full set of multibeam calibration lines were acquired, on flat bottoms and steep targets at about $30 \mathrm{~m}$ water depth. The roll, pitch and yaw correction angles were then used to correct the installation geometries. Calibration parameters were then taken into account during data analysis to correct the observations.

\section{Data analysis and bathymetric map}

Data analysis was performed by the Computer Aided Resource Information System - Hydrographic Information Processing System (CARIS - HIPS) PRO V5.2 software, specifically designed to process multibeam data under Windows $\mathrm{NT}^{\circledR}$ and capable to manage images in a mosaic of the lake floor and produce raster and analytical maps. The processing sequence was as follows:

1. system calibration and multibeam data reprocessing;

2. data quality check: low quality data were discarded due to a not optimal signal to noise ratio;

3. lake level correction, using the RTK data;

4. High and medium frequency spike removal, but keeping intact eventual signatures produced by uprising gas bubbles from the lake floor.;

5. Production of high accuracy Digital Elevation Models (DEM).

To produce the MDEM, were used a total of 1.466.914 million of 3-D punctual data (Latitude, Longitude and depth), that were converted in the UTM33-WGS84 coordinate system.

The survey data set was analysed to reduce any positioning offset or error in the MDEM together with the analysis of the standard deviations of the mutibeam data,. The latter show values ranging between 10-15 cm up to depths of -20m; 15-30 cm at depths between -20 and $-50 \mathrm{~m}$ and 30-50 cm at depths greater than $-50 \mathrm{~m}$.

Once the offsets and errors were analysed and corrected, the final MDEM was produced and made available for the morphostructural analysis, production of contour maps at 1:2.500 scale (Fig. 7) and shaded reliefs (Fig.9,10), which show the roughness and complexity of the crater of the Albano lake.

\section{Discussion and conclusions}

High resolution multibeam technique provided the first 3-D detailed morphobathymetric map of the Albano Lake at $<1 \mathrm{~m}$ average pixel resolution (Fig.7). These data are useful for a wide range of 
applications and to improve and support the geological, geomorphological, volcanological, geochemical, geophysical research and monitoring of this volcanic area.

As far as the a volcanological interpretations is not the specific goal of this paper, which aims to describe the technique used and to shows the first images of the submerged part of the Albano Lake crater, these new data can provide information on the still unknown morphological features of the submerged part of the crater. The groundfloor show the past episodes of the lake's history, strictly connected with the geological and volcanological evolution of the area. Surface features due to volcanic activity, recent surface and lake level changes and sliding or rock fall events, are evident from the data.

The first main results obtained from the bathymetric surveys can be summarized as follows:

- The total water volume of the lake at the time of the surveys is $447.495 .490 \mathrm{~m}^{3}$.

- The lake is characterized in its northern side by a flat area at depth between 0 and $25 \mathrm{~m}$ below lake surface and by two concentric circular basins bordered by steep flanks, which can be addressed to crater rims. The first one is between about - 50 and - $120 \mathrm{~m}$; the second between -120 and $-167 \mathrm{~m}$.

- The deepest point of the lake is at $-166.86 \mathrm{~m}$, lower than the previous measurements (173 m). This value could be explained with the lowering of the water table around the basin which can reduce the hydrologic balance of the area, as reported by Capelli et al., (2000).

- The deepest point coincides with a circular crater $1000 \mathrm{~m}$ wide, with steep inner flanks about $45 \mathrm{~m}$ height. The steep flanks shows erosion phenomena, likely sub aerial, that could be occurred before the crater was filled with water. The flat floor of this area suggest a continuous sedimentation at this depth in agreement with Oldfield et al. (1996).

- Other sub circular depressions size could be addressed to craters. But without further evidences from seismic soundings or drillings, with the exception of those reported in Oldfield et al. (1996), we cannot confirm or exclude this hypothesis.

- Slides or rock fall of different size occurred in the lake since its formation. They mainly occurred along the steepest inner flanks of the crater and partially in the central crater.

- Three levels of submerged shores, at the moment of unknown age, are clearly located at depths between -31 and -41 in the north-eastern side of the lake. They witness the past lake level standings at these heights likely due to change of the environment as also reported by Chondrogianni et al., (1996), Ryves et al. (1996), Lowe et al. (1996) and Marra and Karner (2005).

- Data did not revealed any relevant gas exhalative centres in the whole basin. This is in contrast with previous observations (Oldfield at al., 1996) that evidenced some exhalative points mainly in the eastern side of the basin. This can be explained with a temporary 
change of the gas exhalation from the ground or with the sealing of fractures which prevent the gas release up to the surface.

The issues related with the occurrence of slides and gas exhalative points are relevant for scientific discussion and hazard assessment of the Albano Crater Lake volcano and its bathymetry open new questions on its recent evolution, thus suggesting further investigations through the integration of different geological and geophysical studies. Mainly, if the central deep crater can be a suitable trap for $\mathrm{CO}^{2}$ accumulation that can be suddenly released, as occurred in lake Nyos (Rice 2000), taking into account that the Albano lake has the highest CO2 concentration among the Italian crater lakes (up to $200 \mathrm{mg} / \mathrm{l}$ at $-175 \mathrm{~m}$ ) (Martini et al., 1994). In such case, it should be subjected to a water rollover with dangerous consequences of gas or hot fluids release from the deepest part of the lake. Concerning slides, a slide hazard must be taken into account because their occurrence would induce tsunami lake waves, dangerous for humans and the environment. Some cases of tsunamis triggered by slides in closed basin, are reported in the literature such as that occurred in the artificial lake of Vajont, Italy, in 1963 which produced large desctruction and about two thousand of victims. So far, the occurrence of such events in the Albano lake should not be excluded due to the seismicity of the area, the features of the lake floor and to the steep slopes of the inner side of the crater facing the lake. The morphological features of the lake floor, suggest the existence of at least two larger craters and three more coalescent smaller eruptive centres (Anzidei et al., 2006). Further surveys, such as seismic soundings and sub bottom profiles, should be performed to provide data on the still unknown structural features of the lake floor.

\section{Acknowledgements}

Surveys were performed under the Colli Albani Project V-3 funded by the Italian Dipartimento della Protezione Civile. We wish to tank Luca Pizzino, Maria Luisa Carapezza, Piergiorgio Scarlato of INGV and Guido Giordano of the University of Roma Tre for the fruitful discussion on the results.

\section{References}

Amato A, Chiarabba C (1995) Recent uplift of the Alban Hills Volcano (Italy): evidence for magmatic inflation? Geophysical Research Letters 22: 1985-1988

Amato A, Chiarabba C, Cocco M, Di Bona M, Selvaggi G (1994) The 1989-1990 seismic swarm in the Alban Hills volcanic area, central Italy. Journal of Volcanology and Geothermal Research 61: 225-237

Andretta D. and Voltaggio M. (1988): La cronologia recente del vulcanismo dei Colli Albani. Le Scienze, 41 (243), 26-36 
Annunziatellis A, Ciotoli G, Lombardi S, Nolasco F (2003) Short- and long-term gas hazard: the release of toxic gases in the Alban Hills volcanic area (central Italy). Journal of Geochemical Exploration 77: 93-108

Anzidei M, Baldi P, Casula G, Galvani A, Riguzzi F, Zanutta A (1998) Evidence of active crustal deformation of the Colli Albani volcanic area (central Italy) by GPS surveys. Journal of Volcanology and Geothermal Research 80: 55-65

Anzidei M. (2000): Rapid bathymetric surveys in marine volcano areas: a case study in Panarea aera. Phys. Chem. Earth (a), Vol. 25, No.1, pp. 77-80.

Anzidei M., Esposito A., Bortoluzzi G., De Giosa F. (2005): the first high resolution bathymetric map of the exhalative area of Panarea (Aeolian islands, Italy). Annals of Geophysics, 48, 6, 17-39

Marco Anzidei, Maria Luisa Carapezza, Guido Giordano, Matteo Lelli and Luca Tarchini (2006); New discoveries on the Albano Maar Lake from high resolution bathymetry and dissolved $\mathrm{CO}_{2}$ budget (Colli Albani volcano, Central Italy). Earth and Planetary Science Letters, submitted

Barberi F., Chelini F., Marinelli G., Martini M. (1989): The gas cloud of Lake Nyos (Cameroon, 1986): results of the Italian technical mission. Jou. Volc. Geoth. Res., 39, 125-134.

Beaubien SE, Ciotoli G, Lombardi S (2003) Carbon dioxide and radon gas hazard in the Alban Hills area (central Italy). Journal of Volcanology and Geothermal Research 123: 63-80

Capelli G., Mazza R., Giordano G., Cecili A., De Rita D., Salvati D. (2000): The Colli Albani Volcano (Rome, Italy): equilibrium breakdown of a hydrogeological unita as a results of unplanned and uncounted over exploitation. Hydrogeologique, 4, 63-70

Carandini A. (1997): La nascita di Roma: dei, Lari, eroi e uomini all’alba di una civiltà. Einaudi eds., 766 pp.

Carapezza ML, Badalamenti B, Cavara L, Scalzo A (2003) Gas hazard assessment in a densely inhabited area of Colli Albani Volcano (Cava dei Selci, Roma). Journal of Volcanology and Geothermal Research 123: 81-94

CARIS-HIPS (Hydrographic Information Processing System) and SIPS professional v.5.2 software User Guide: (2002): MA-HIPS-UG-02-02 www.caris.com. 264 Rookwood av. Fredericton, Canada.

Chiarabba C, Amato A, Delaney PT (1997) Crustal structure, evolution, and volcanic unrest of the Alban Hills, Central Italy. Bulletin of Volcanology 59: 161-170

Chiarabba C., Jovane L., Di Stefano R. (2005): A new view of Italian seismicity using 20 years of instrumental seismicity. Tectonophysics vol. 395, pp. 251-268

Chiodini G, Frondini F (2001) Carbon dioxide degassing from the Alban Hills volcanic region, Central Italy. Chemical Geology 177: 67-83

Chondrogianni C., Ariztegui D., Niessen F., Ohlendorf C., Lister G. (1996): Late Pleistocene and Holocene sedimentation in Lake Albano and Lake Nemi (central Italy). Guilizzoni G. and Oldfield F., Guest Eds. Paleoenvironmental Analysis of Italian Crater Lake and Adriatic sediments. Mem. Ist. Ital. Idrobiol., 55, 23-38 
De Rita D, Funiciello R, Parotto M (1988) Carta Geologica del Complesso vulcanico dei Colli Albani (Geological map of the Colli Albani volcanic complex), scale 1:50,000, Consiglio Nazionale delle Ricerche

De Rita D, Funiciello R, Rosa C (1992) Volcanic activity and drainage network evolution of the Alban Hills area (Rome, Italy). Acta Vulcanologica 2: 185-198

De Rita D, Giordano G, Esposito A, Fabbri M, Rodani S (2002) Large volume phreatomagmatic ignimbrites from the Colli Albani volcano (Middle Pleistocene, Italy). Journal of Volcanology and Geothermal Research 118: 77-98

Esposito A., Giordano G., Anzidei M. (2006): The 2002-2003 submarine gas eruption at Panarea island (Aeolian archipelago, Italy): structure and volcanology of the seafloor and implications for hazard evaluation. Marine Geology, 227, 119-134

Fornaseri M, Scherillo A, Ventriglia U (1963) La regione vulcanica dei Colli Albani (Vulcano Laziale). Consiglio Nazioale delle Ricerche Roma, 550 pages

Funiciello R, Giordano G, De Rita D, Carapezza ML, Barberi F (2002) L'attività recente del cratere del Lago Algano di Castelgandolfo. Rendiconti dell'Accademia dei Lincei (Scienze Fisiche e Naturali) ser. 9, 13: 113-143

Funiciello R, Giordano G, De Rita D (2003) The Albano maar lake (Colli Albani Volcano, Italy): recent volcanic activity and evidence of pre-Roman Age catastrophic lahar events. Journal of Volcanology and Geothermal Research 123: 43-61

Giordano G, De Rita D, Cas RAF (2002a) Valley pond and ignimbrite veneer deposits in the smallvolume phreatomagmatic 'Peperino Albano' basic ignimbrite, Lago Albano maar, Colli Albani volcano, Italy: influence of topography. Journal of Volcanology and Geothermal Research 107: 131-144

Giordano G, De Rita D, Fabbri M, Rodani S (2002b) Facies associations of rain-generated versus crater lake-withdrawal lahar deposits from Quaternary volcanoes, central Italy. Journal of Volcanology and Geothermal Research 118: 145-159

International Hydrographic Organization (IHO) Special publication S-44 "Standards for hydrographic surveys” 4th edition, April 1998

Karner DB, Marra F, Renne PR (2001a) The history of the Monti Sabatini and Alban Hills volcanoes: groundwork for assessing volcanic-tectonic hazards for Rome. Journal of Volcanology and Geothermal Research 107: 185-219

Karner DB, Marra F, Florindo F, Boschi E (2001b) Pulsed uplift estimated from terrace elevations in the coast of Rome: evidence for a new phase of volcanic activity? Earth and Planetary Science Letters 188: 135-148

Lowe J.J., Accorsi C.A., Bandini Mazzanti M., Bishop A., Van Der Kaars S., Forlani L., Mercuri A.M., Rivalenti C., Torri P., Watson C. (1996): Pollen stratigraphy of sediment sequences from lakes Albano and Nemi and from central Adriatic. Guilizzoni G. and Oldfield F., Guest Eds. Paleoenvironmental Analysis of Italian Crater Lake and Adriatic sediments. Mem. Ist. Ital. Idrobiol., 55, 71-98 
Manca M., Nocentini A.M., Belis C., Comoli P., Corbella L. (1996): Invertebrate fossil remains and paleoenvironmental reconstruction. Guilizzoni G. and Oldfield F., Guest Eds. Paleoenvironmental Analysis of Italian Crater Lake and Adriatic sediments. Mem. Ist. Ital. Idrobiol., 55, 160-173

Marra F, Freda C, Scarlato P, Taddeucci J, Karner DB, Renne PR, Gaeta M, Palladino DM, Trigila R, Cavarretta G (2003) Post-caldera activity in the Albani Hills volcanic district (Italy): ${ }^{40} 40 \mathrm{Ar} /{ }^{39} \mathrm{Ar}$ geochronology and insights into magma evolution. Bulletin of Volcanology 65: 227-247, DOI: 10.1007/s00445-002-0255-9

Marra F., Carner D. B. (2005) The Albano maar (Alban Hills volcanic district, Italy): active or dormant volcano? Il Quaternario 18-2, 173-185.

Martini M., Giannini L., Prati F., Tassi F., Capaccioni B., Iozzelli P., 1994. Chemical characters of crater lakes in the Azores and Italy: the anomaly of Lake Albano. Geochem. J., 28: 173-184.

Meli R. (1911): Intorno l’origine dei due laghi Albano e Nemorense. Ristampa di una dissertazione scritta nel 1758 dal dott. Giovanni Girolamo, Lapi Romano, con indicazione dei naturalisti, che nella seconda metà del secolo XVIII parlarono dei monti vulcanici dell'antico Lazio. Bollettino della Società Geologica Italiana, vol. XXX, pp.981-1006.

Mercalli (1883): Vulcani e fenomeni Vulcanici. In: G. Negri, A. Stoppani, G. Mercalli (eds): Geologia d'Italia 3rd part. Milano, 374 pp.

Oldfield F. (1996): The PALICLAS Project: synthesis and overview. Guilizzoni G. and Oldfield F., Guest Eds. Paleoenvironmental Analysis of Italian Crater Lake and Adriatic sediments. Mem. Ist. Ital. Idrobiol., 55, 329-357.

Palladino DM, Gaeta M, Marra F (2001) A large K-foiditic hydromagmatic eruption from the early activity of the Alban Hills Volcanic District, Italy. Bulletin of Volcanology 63: 345-359, DOI: $10.1007 / \mathrm{s} 004450100150$

Porreca M, Mattei M, Giordano G, De Rita D, Funiciello R (2003) Magnetic fabric and implications for pyroclastic flow and lahar emplacement, Albano maar, Italy. Journal of Geophysical Research 108, DOI 10.1029/2002JB002102

RESON B.V. Denmark PDS 2000 hydrographic surveys data acquisition and processing software

Rice A. (2000): Rollover in volcanic crater lakes: a possible cause for Lake Nyos type disaster. Jou. Volc. Geoth. Res., 97, 233-239.

Ryves D.B., Jones V.G., Guilizzoni P., Lami A., Marchetto A., Battarbee R.W., Bettinetti R., Devo E.C. (1996): Late Pleistocene and Holocene environmental changes at lake Albano and Nemi as indicated by algal remains. In P.Guilizzoni, F. Oldfield Eds., Paleoenviromental analysis of Italian crater lakes and Adriatic sediments (PALICLAS). Mem. Ist. It. Idrobiol., 55, 119-148

Salvi S., S. Atzori, C. Tolomei, J. Allievi, A. Ferretti, C. Prati, F. Rocca, S. Stramondo and N. Feuillet (2004): Inflation rate of the Colli Albani volcanic complex retrieved by the Permanent Scatterers SAR interferometry technique, /Geophysical Research Letters/, VOL. 31, L12606, doi:10.1029/2004GL020253. 
Serpelloni E., M. Anzidei, P. Baldi, G. Casula, A. Galvani (2005): Crustal Velocity and Strain-Rate fields in Italy and Surrounding Regions: New Results From the Analysis of Permanent and NonPermanent GPS Networks, Geoph. Jou. Int. in press

Sigurdsson H., Devine J.D., Tchova F.M., Presser T.S., Pringle M.K.W., Evans W.C. (1987): Orogin of the lethal gas burst from Lake Monoun, Cameroon. Jou. Volc. Geoth. Res., 31, 1-16.

Trigila R (editor) (1995) The volcano of the Alban Hills. Tipografia SGS, Rome, 283 pages

Villa IM, Calanchi N, Dinelli E, Lucchini F (1999) Age and evolution of the Albano crater lake (Roman Volcanic Province). Acta Vulcanologica 11: 305-310 


\section{Figure caption}

Fig.1 Regional setting of the Colli Albani volcanic complex (from De Rita al., 1992, modified). Key: 1=travertine; 2=Plio-Pleistocene sedimentary units; 3="final" hydromagmatic units; 4=air fall deposits; 5=lava flows; 6=pyroclastic flow units of the Colli Albani; $7=$ =pyroclastic flow units of the Sabatini volcanic field (in northwestern part of the map); $8=$ Tortonian flysch; $9=$ caldera rims; 10=late explosion craters (a: Ariccia, b: Nemi, c: Albano, d: Giuturna, e: Valle Marciana, f: Pantano Secco, g: Prata Porci, h: Castiglione); 11=Meso-Cenozoic pelagic carbonate units (Sabina facies); 12=Meso-Cenozoic carbonate platform units (Latium-Abruzzi facies). Black dots are the fiducial GPS station of INGR, and the reference station of ALBA. The latter was used as reference for the real time positioning of the vessel during bathymetric surveys

Fig.2 The ALSEA vessel used during bathymetric surveys of the Albano lake.

Fig.3 Sketch of the instrumentation used during surveys

Fig.4 Course over the ground performed by ALSEA vessel during bathymetric surveys. The 30\% overlapping between nearby lines guarantee the full coverage of the area.

Fig.5 sketch of the swath with the multibeam head in a) vertical and b) rotated positions to collect data up to the lake surface.

Fig.6 a) Temperature and b) conducibility vertical profiles from lake surface to the bottom. Data were collected above the central crater (deepest point of the lake) and were used to calibrate the multibeam system for sound speed velocity in the water to determine depths at $1 \mathrm{~cm}$ average formal accuracy.

Fig.7 Digital Elevation Model (DEM) showing the morphobathymetry of the area. Scale colour shows depths ranging between 0 and $-167 \mathrm{~m}$ a) shaded relief b) at $5.0 \mathrm{~m}$ countour level.

Fig.8 Multibeam image of the central crater

Fig. 9 a,b,c,d Multibeam images of slides located along a,b) the north eastern side and c,d) the southern side of the crater, respectively. In $9 \mathrm{~d}$ are also reported the isobaths to evidence the morphological changes in the slide area.

\section{Table caption}

Tab.1 Instrumentation used during the bathymetric surveys.

Tab.2 Coordinates of INGR station and ALBA stations (WGS84, ellipsoidal heights). 


\begin{tabular}{|c|c|c|}
\hline \multicolumn{3}{|c|}{ Albano Lake Bathymetry - instrumental features } \\
\hline instrumentation & Type & features \\
\hline Vessel & M/B ALSEA & - \\
\hline $\begin{array}{l}\text { Differential GPS receiver } \\
\text { (RTK mode) }\end{array}$ & Ashtech - Aquarius 02 & $\begin{array}{l}10 \mathrm{~mm}+0.5 \mathrm{ppm}, \mathrm{XY} \\
20 \mathrm{~mm}+1.0 \mathrm{ppm}, \mathrm{Z}\end{array}$ \\
\hline Multi beam & $\begin{array}{l}\text { Reson SeaBat } 8125 \\
\text { Reson SeaBat } 8101\end{array}$ & $\begin{array}{l}\text { Frequency } 455 \mathrm{KHz} \\
\text { Angle } 120^{\circ} \\
\text { Beams } 240 \\
\text { Swath } 0.5^{\circ} \text { x } 1.0^{\circ} \\
\text { Max depth } 120 \mathrm{~m} \\
\text { Resolution } 6 \mathrm{~mm} \\
\text { Frequency } 240 \mathrm{KHz} \\
\text { Angle } 150^{\circ}-210^{\circ} \\
\text { Beams } 101 \\
\text { Swath } 1.5^{\circ} \text { x } 1.5^{\circ} \\
\text { Max depth } 300 \mathrm{~m} \\
\text { Resolution } 12.5 \mathrm{~mm}\end{array}$ \\
\hline Gyrocompass & SG BROWN Meridian & $\begin{array}{l}0.05^{\circ} \text { static secant latitude } \\
0.2^{\circ} \text { dynamic secant latitude }\end{array}$ \\
\hline Velocity sounder & NAVITRONIC SVP 15 & $\begin{array}{l}\text { Resolution } 0.1 \mathrm{~m} / \mathrm{s} \\
\text { Accuracy } \pm 0.25 \mathrm{~m} / \mathrm{s}\end{array}$ \\
\hline CTD & MICROCAT SBE 37 - SI & $\begin{array}{l}\text { Conductivity accuracy } 0.0003 \mathrm{~S} / \mathrm{m} \\
\text { Temperature accuracy } 0.002^{\circ} \mathrm{C}\end{array}$ \\
\hline Motion Sensor & TSS DMS 2 - 05 & $\begin{array}{l}\text { Waves } \\
\text { Static accuracy } 5 \mathrm{~cm} \\
\text { Dynamic accuracy } 0 \div 20 \mathrm{sec} \text {. Period } \\
\quad \text { Pitch and roll } \\
\text { Static accuracy } 0.025^{\circ} \\
\text { Dynamic accuracy } 0.03^{\circ} \pm 5^{\circ}\end{array}$ \\
\hline On board Computers & $\begin{array}{l}\text { Pentium IV - Windows } \\
2000\end{array}$ & Data acquisisition \\
\hline Software & RESON B.V. PDS 2000 & navigation and data analysis \\
\hline Software & CARIS HIPS 5.2 & data analysis \\
\hline Software & ArcView GIS 8.2 & data management \\
\hline
\end{tabular}

Table 1

\begin{tabular}{|l|l|l|l|}
\hline \multicolumn{4}{|c|}{ Albano Lake bathymetry - Reference survey coordinates } \\
(WGS84, UTM33) \\
\hline Station & geographic & UTM & Height (m) \\
\hline ALBA (Tyrgeonet) & Lat N 38 $37^{\prime} 58.909$ & N 4276057.468 & 144.554 \\
& Lon E $15^{\circ} 04^{\prime} 26.457$ & E 506442.1583 & \\
\hline INGR & Lat N 38 $38^{\circ} 16.772$ & N 4276608.335 & 43,30 \\
& Lon E $15^{\circ} 04^{\prime} 40.257$ & E 506775.313 & \\
\hline
\end{tabular}

Table 2 


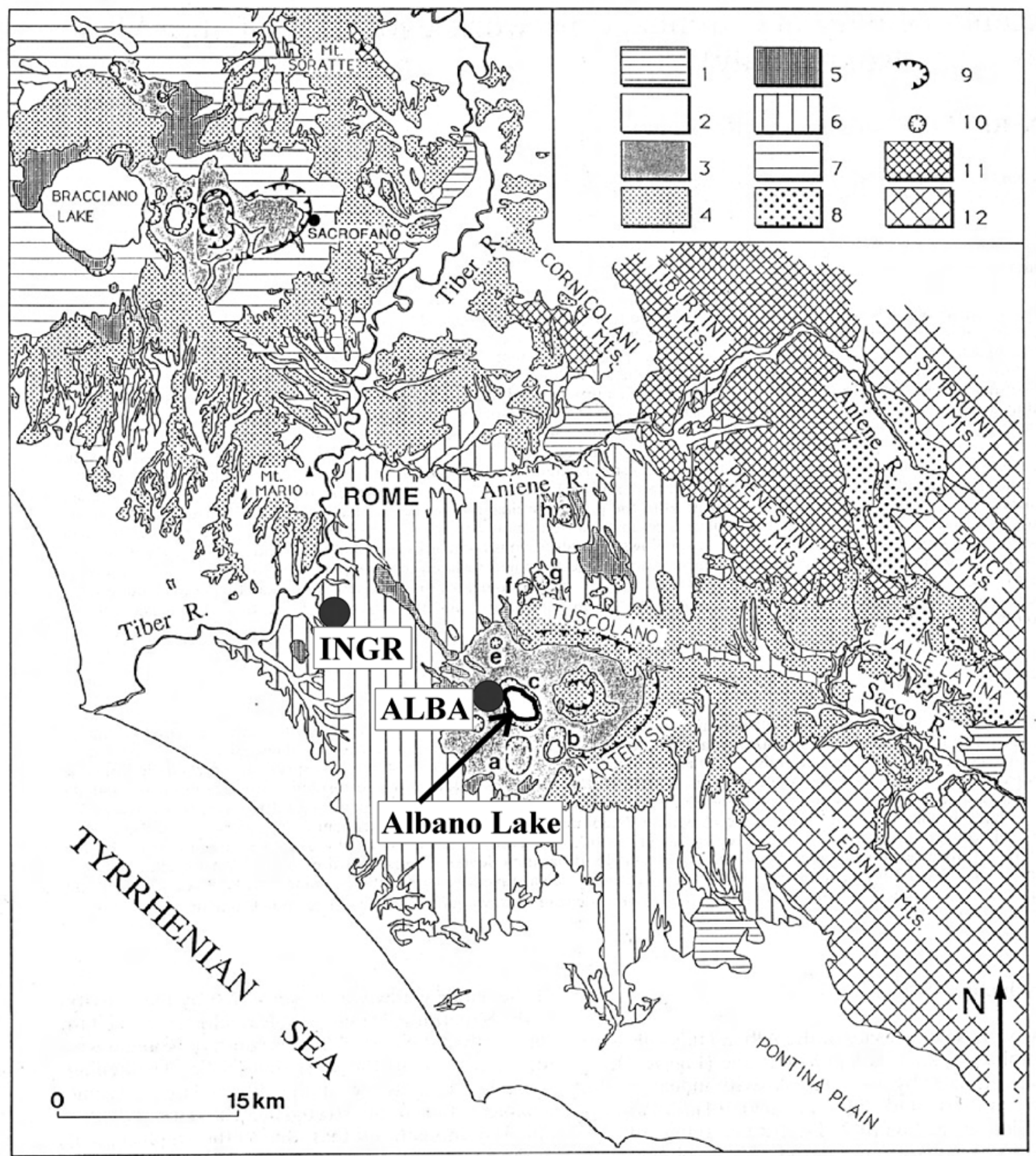




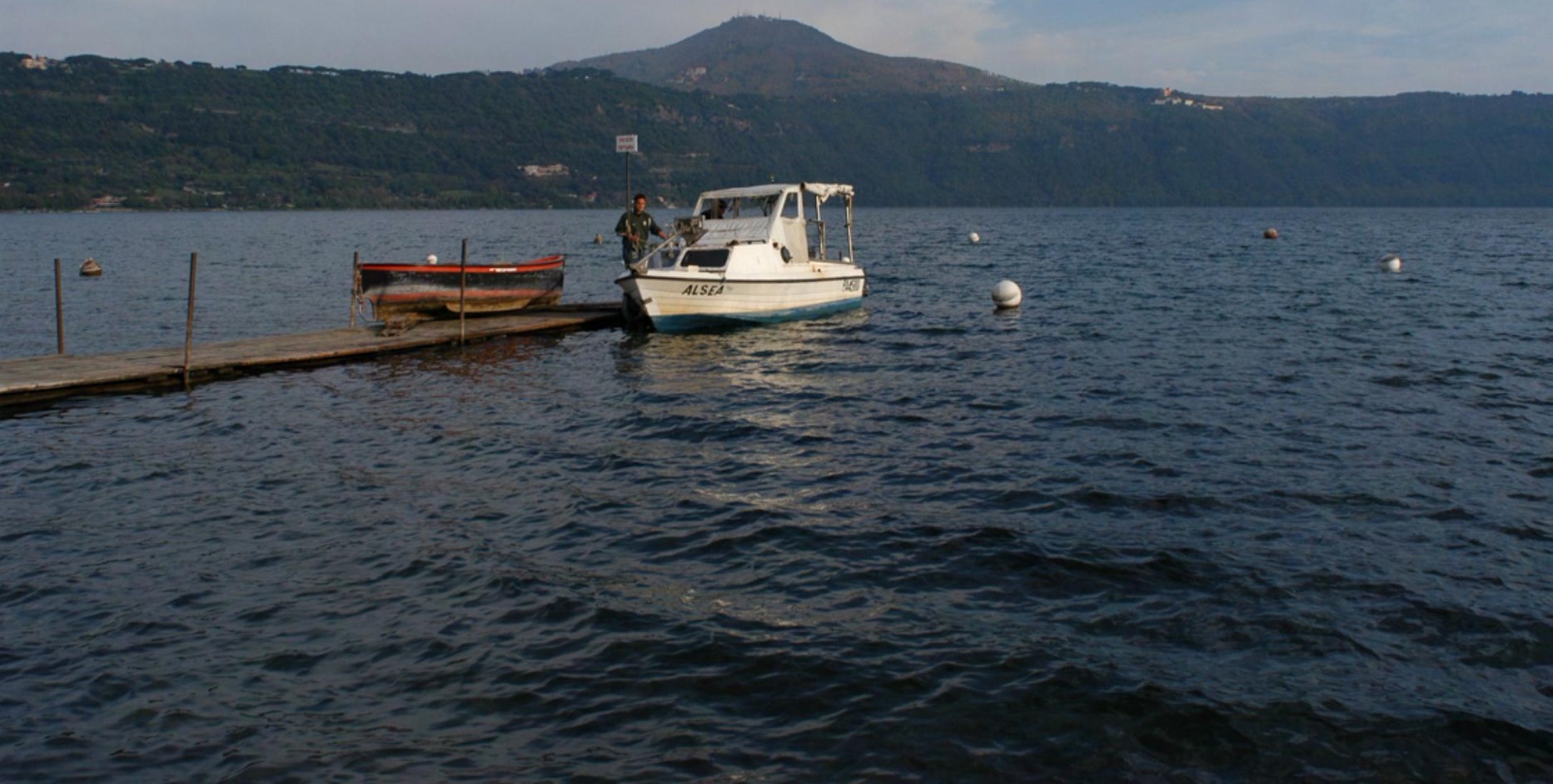




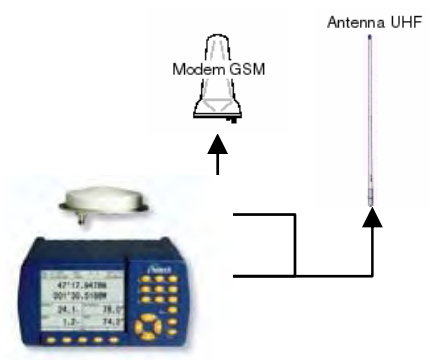

UHF: Pseudorange Correction GSM: RTCM - SC104

GPS (RTK) - BASE

Receiver ASHTECH Aquarius02
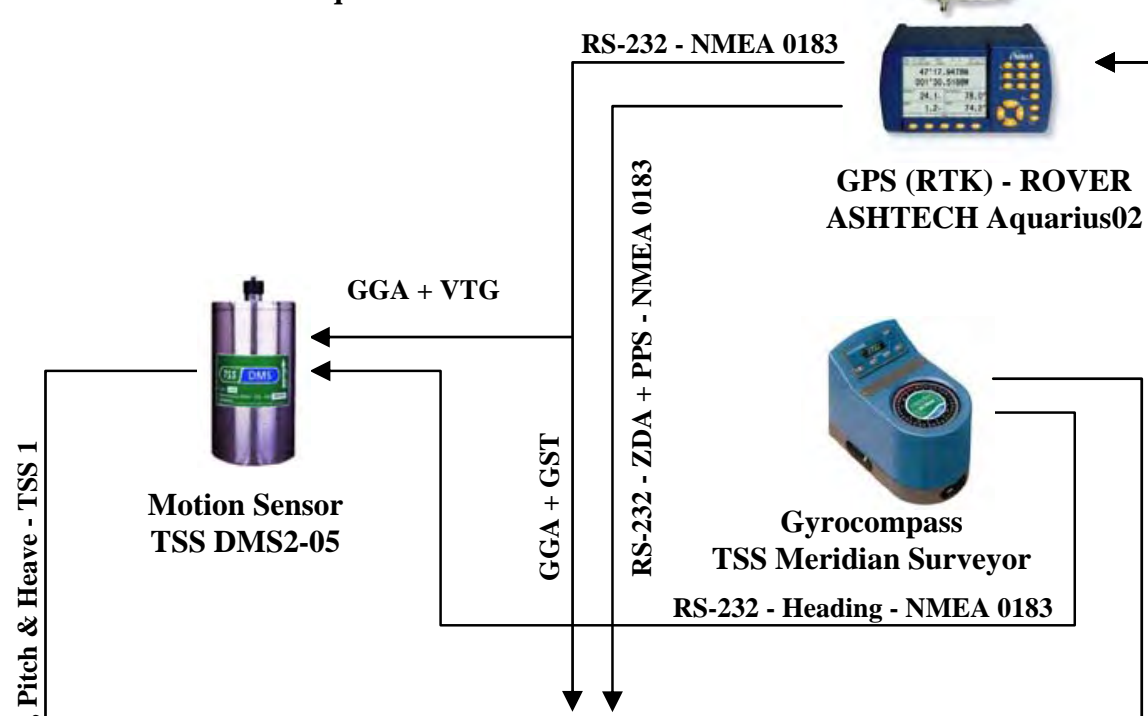

RS-232 - Heading - NMEA 0183

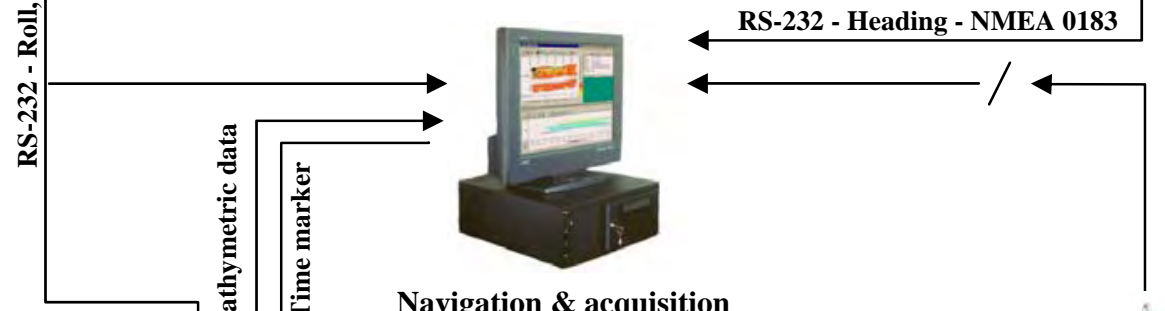

กิ

ณิ

System

THALES - PDS 2000

至

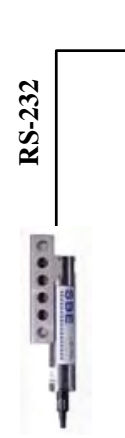

Velocity sound SBE37-SI

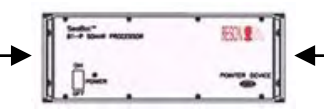
multi beam processor RESON 81-P

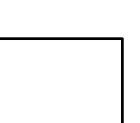

章

Velocity sound

RESON SVP-15

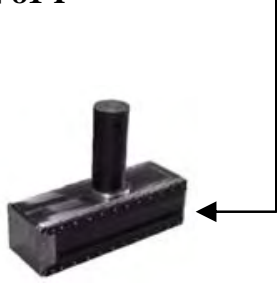

施

요

है

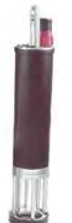

Fig. 3 


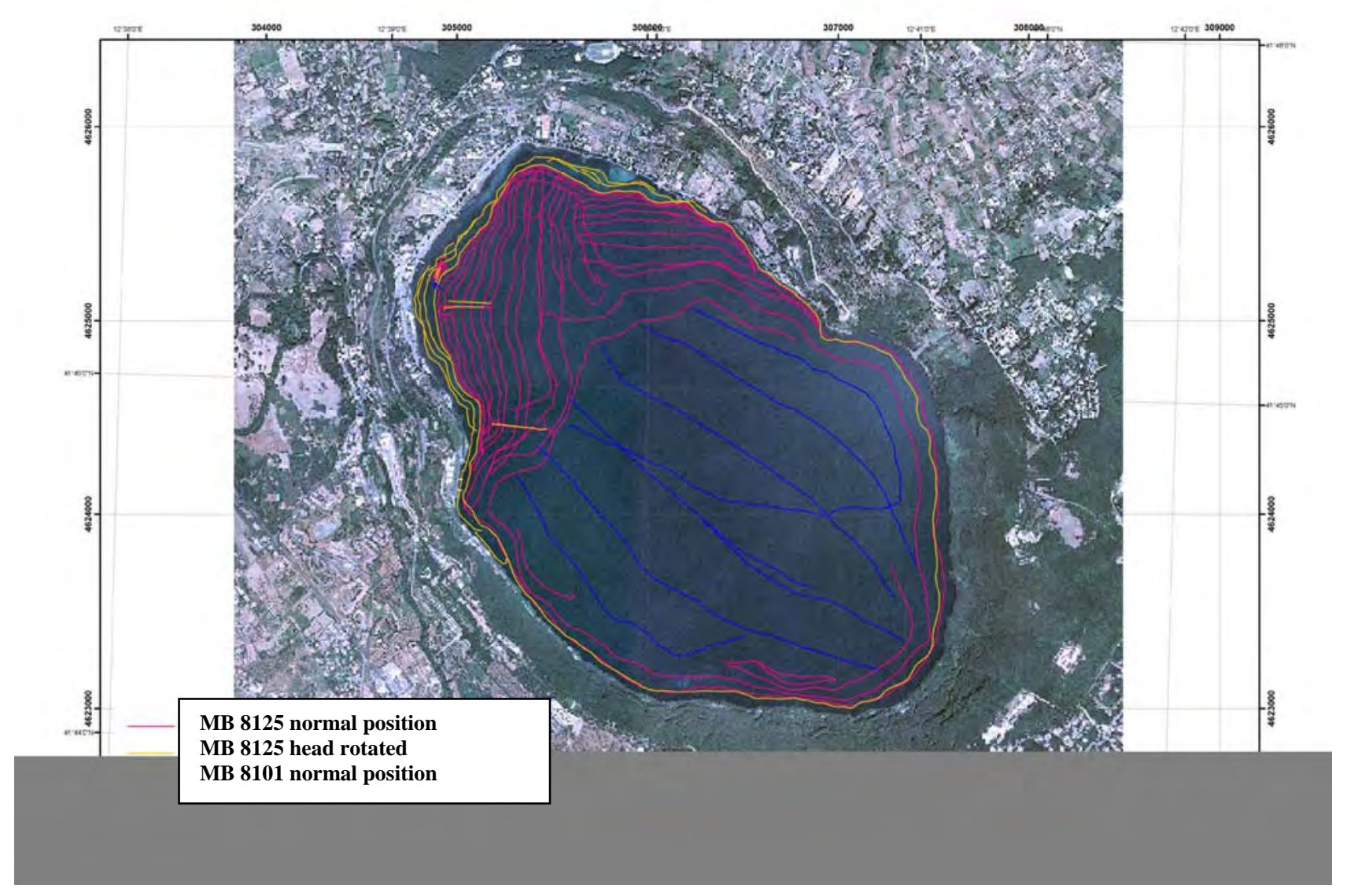

Fig. 4 

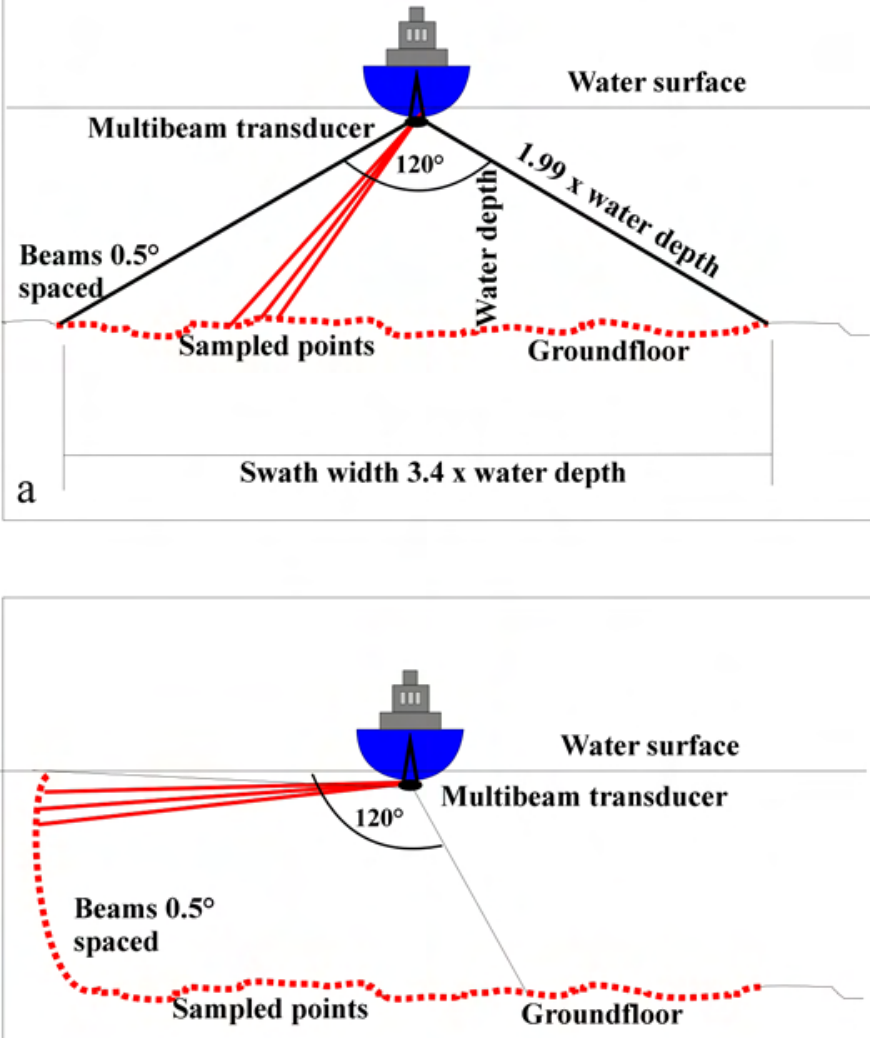

$\mathrm{b}$ 
TP03

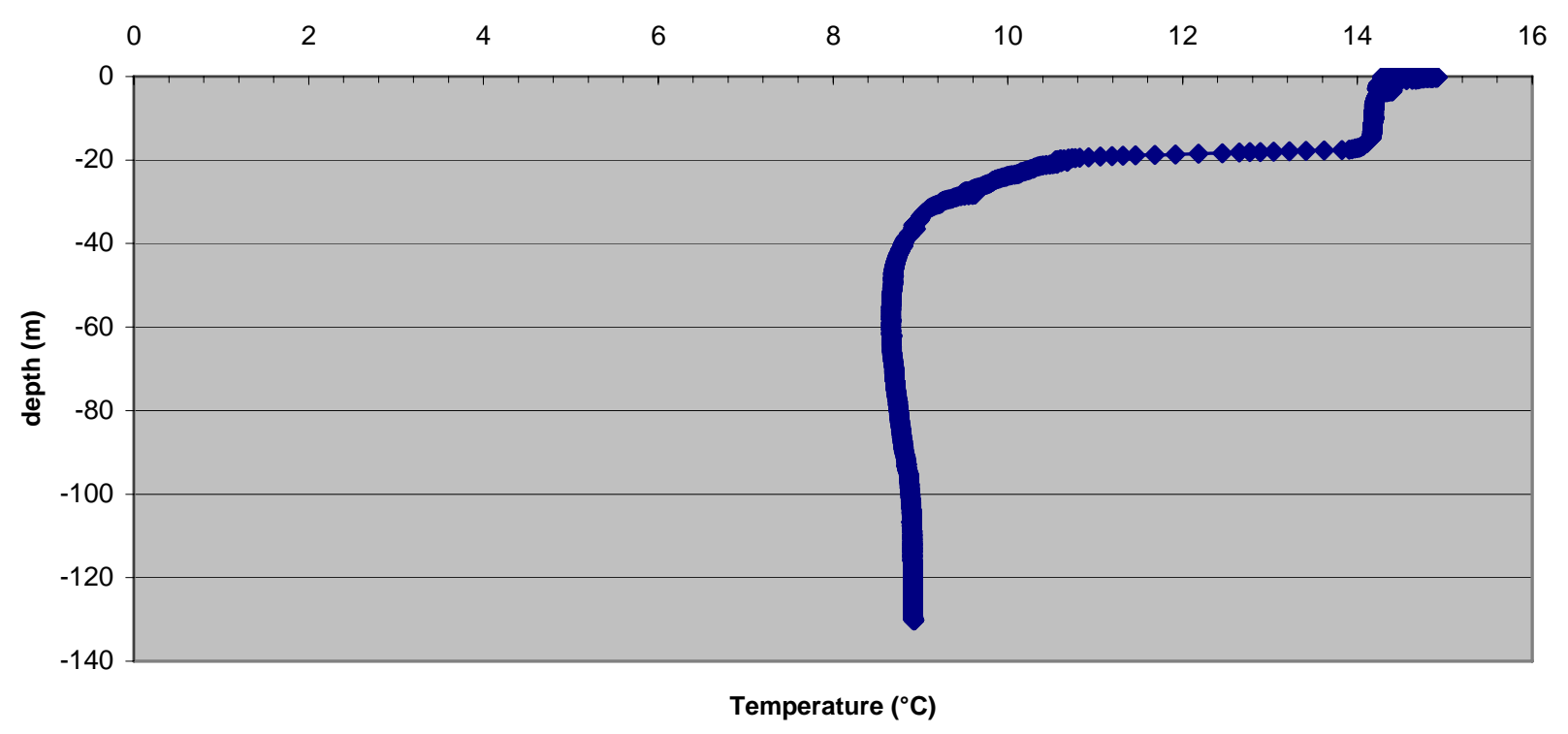

CP03

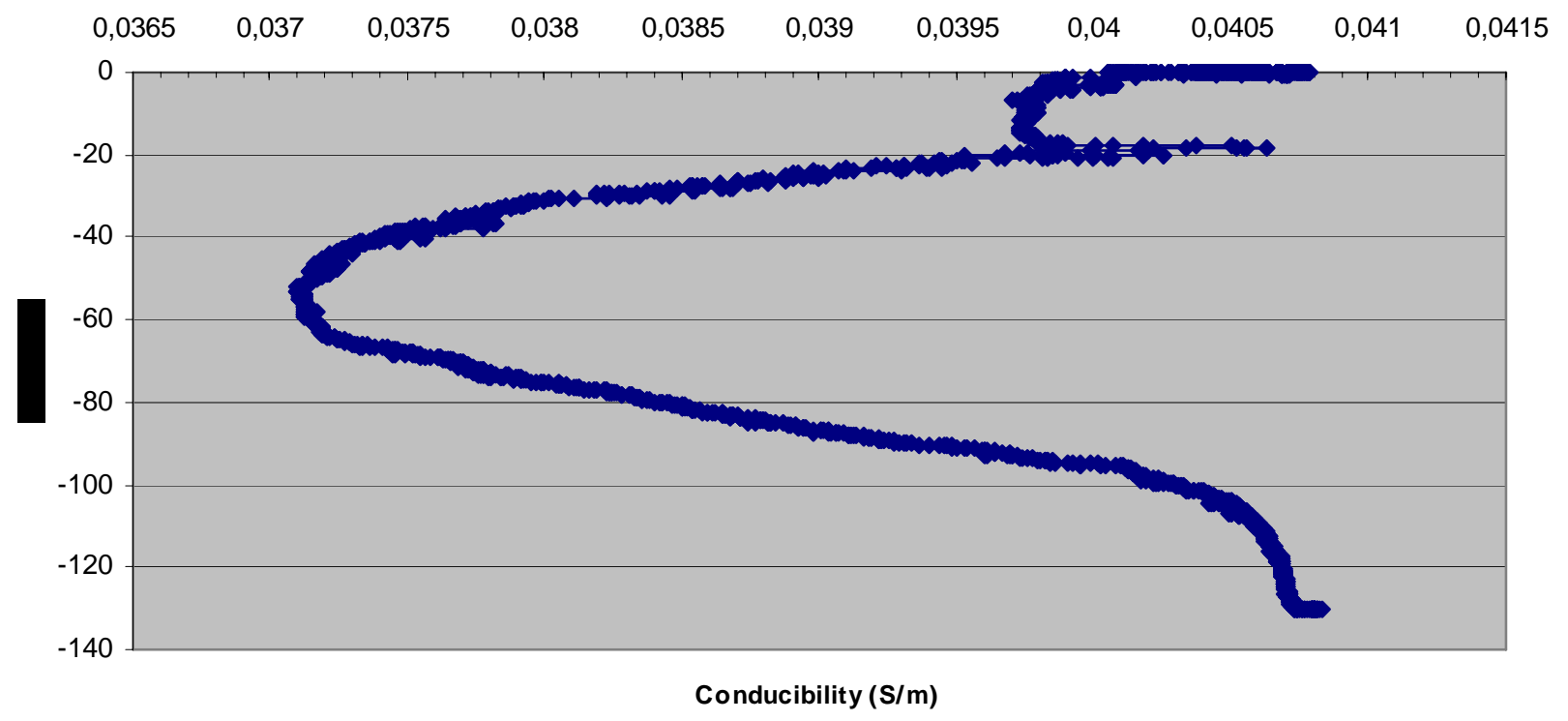


CP04

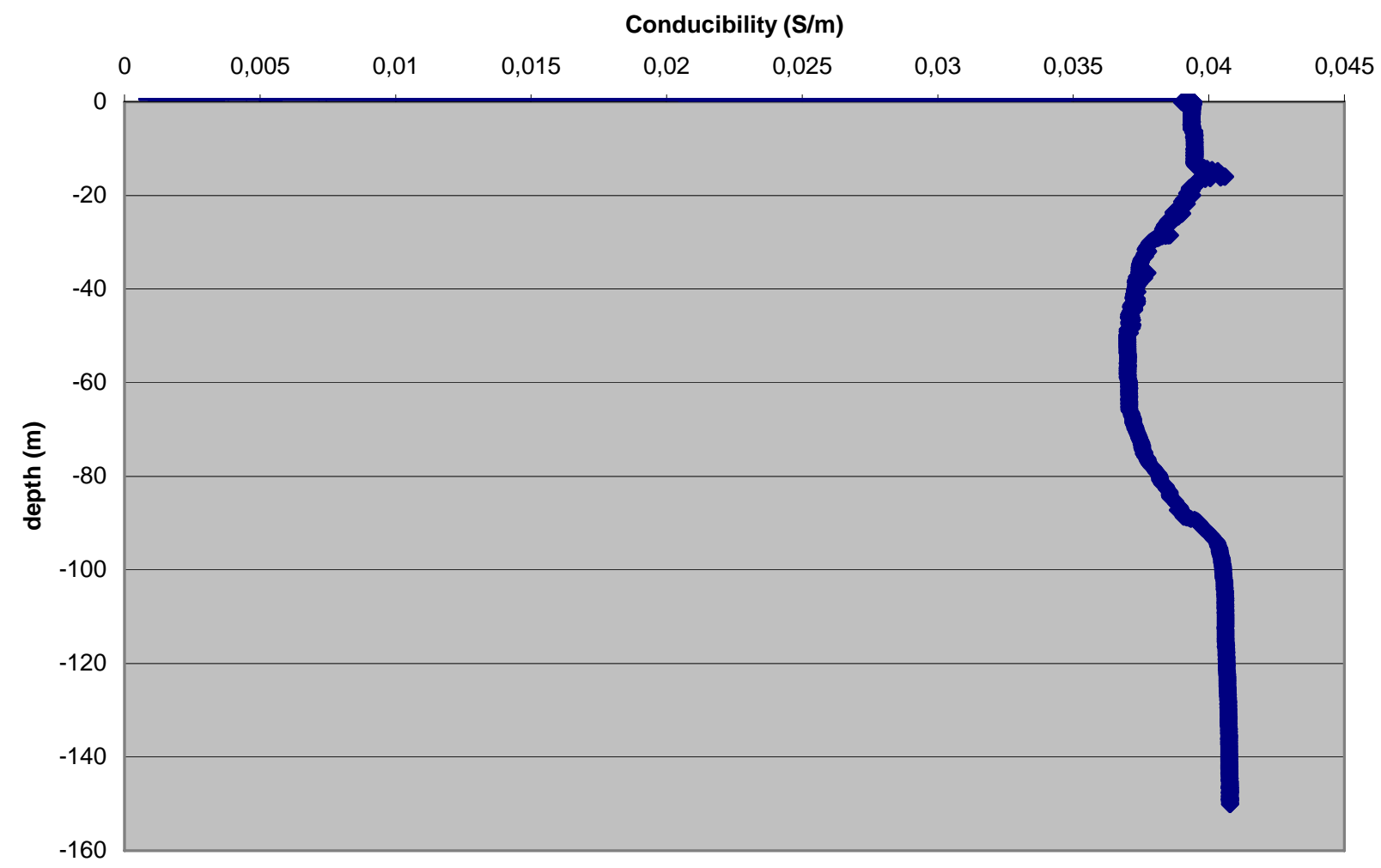


TP04

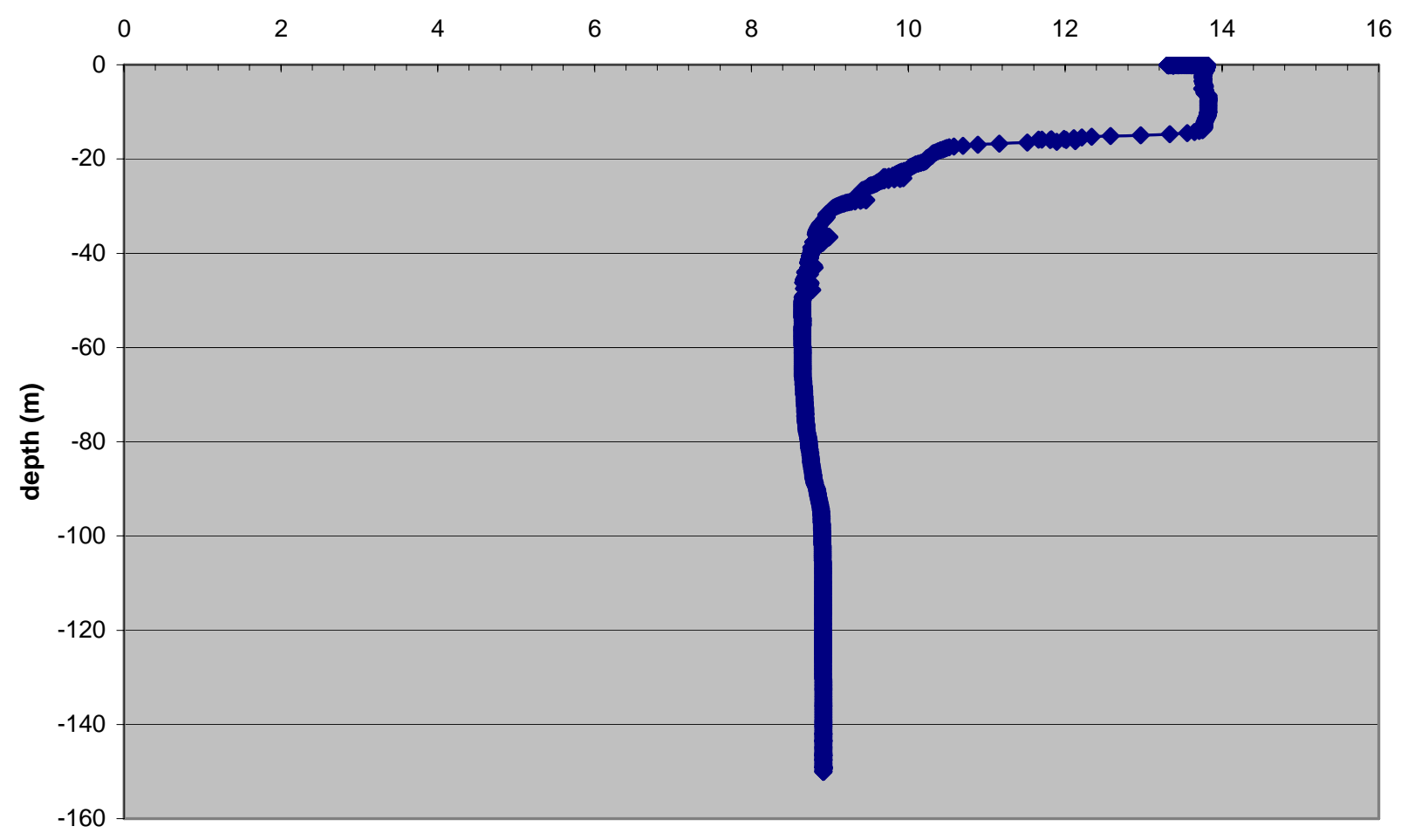

Temperature $\left({ }^{\circ} \mathrm{C}\right)$ 


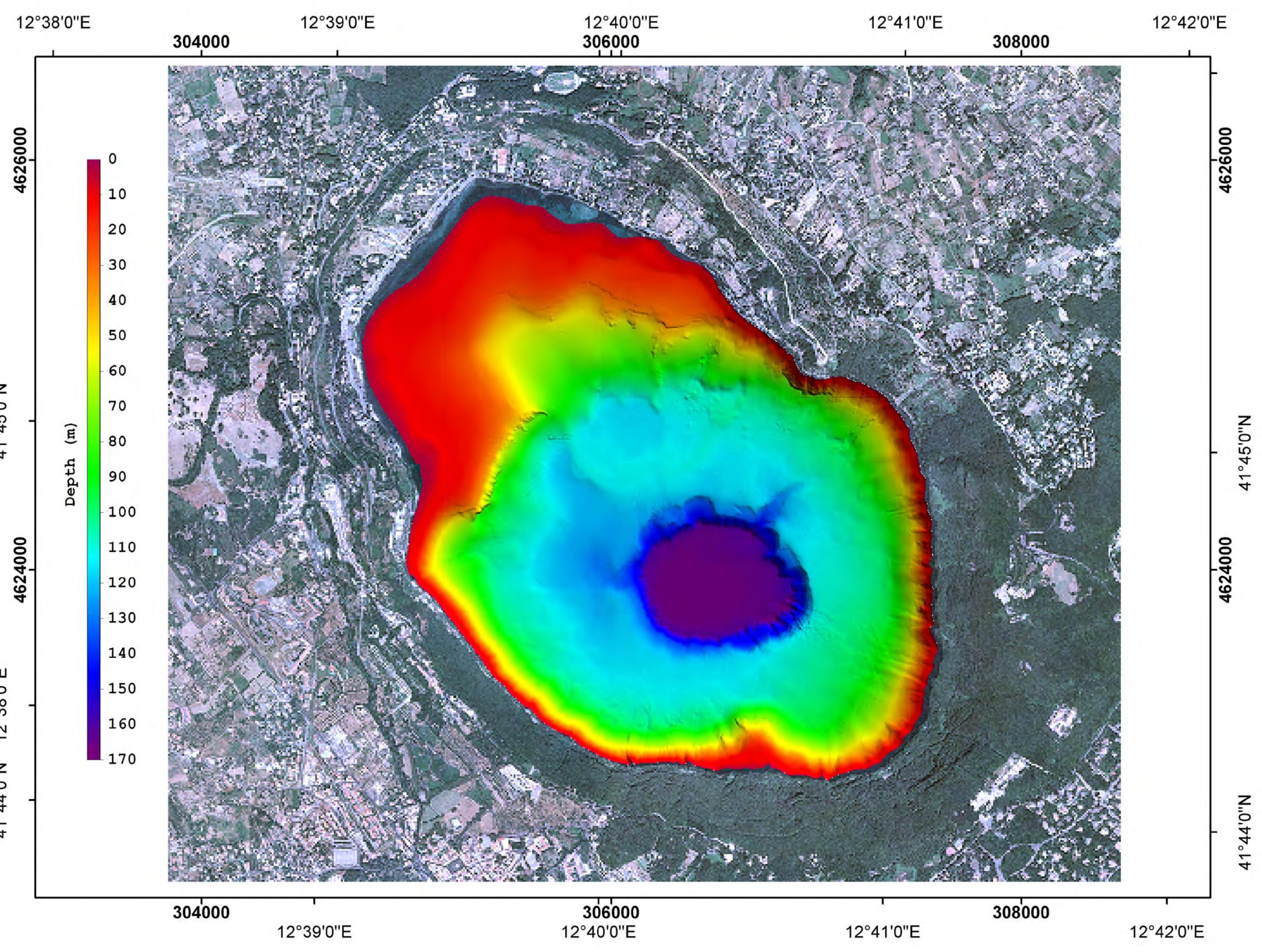




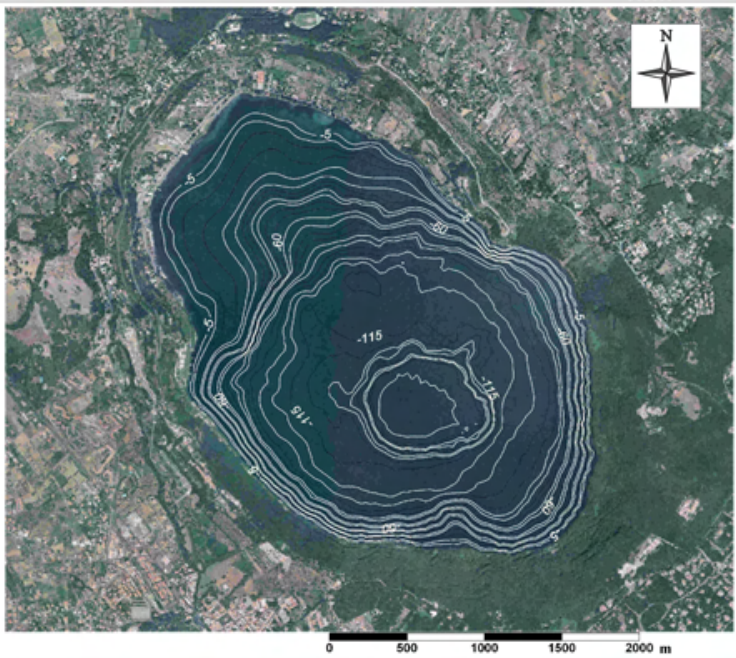

$41^{\circ}+6^{\circ} 0^{*} \mathrm{~N}$

4626000

$41^{\circ} 45^{\circ} 0^{\prime \prime}$

$41^{\circ} 44^{\prime} 0^{*}$ 


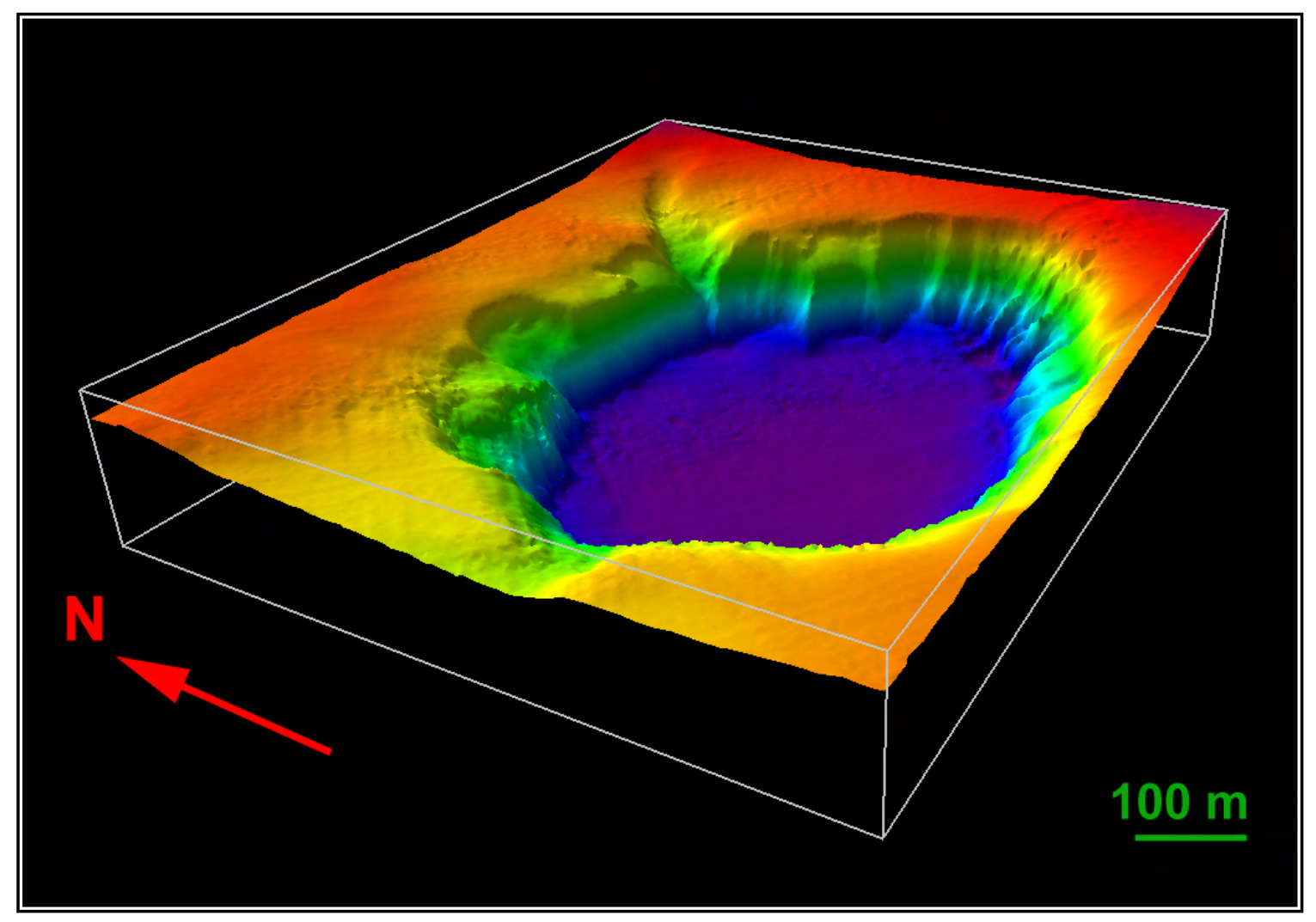

Fig. 8 


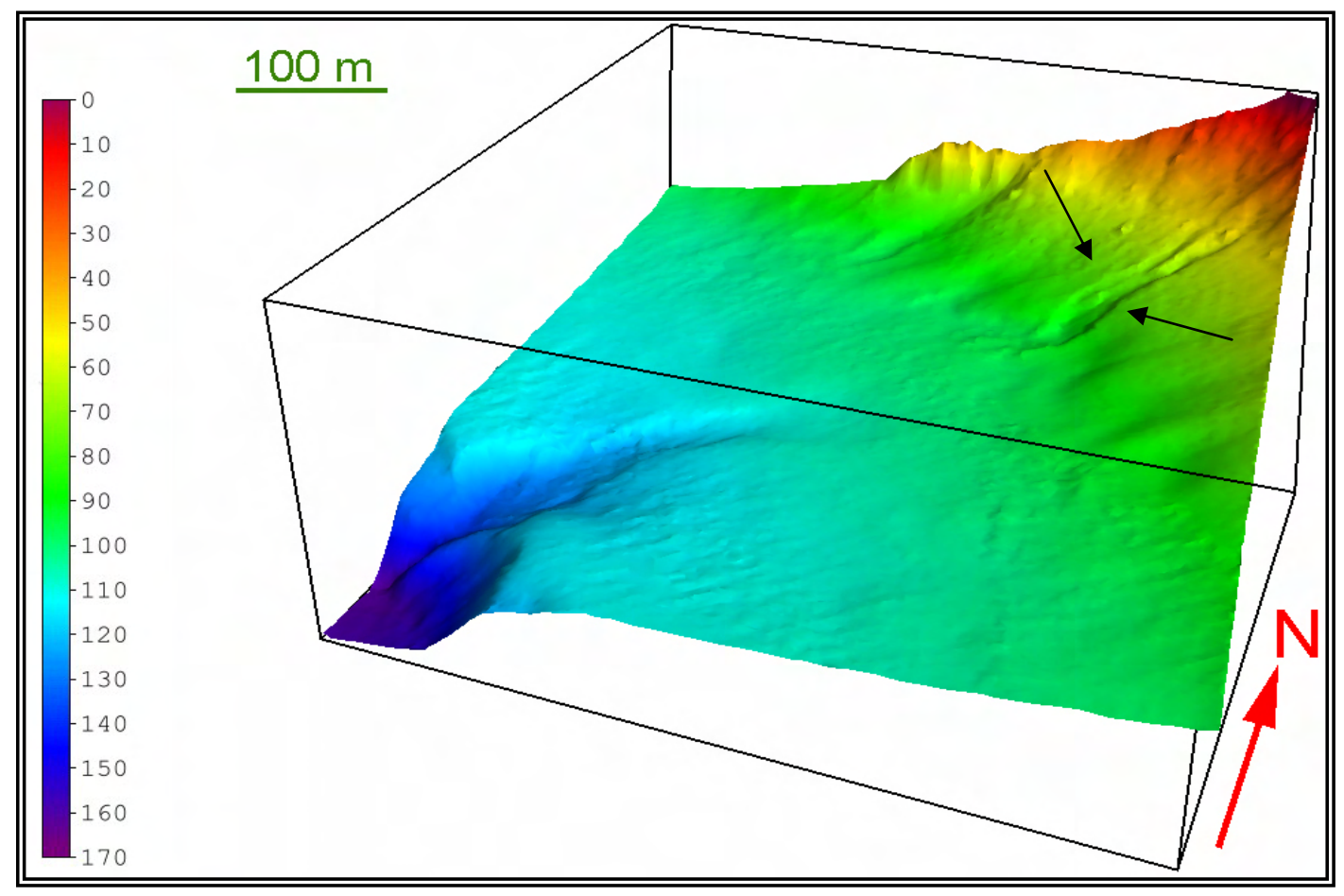

Fig. 9 a 


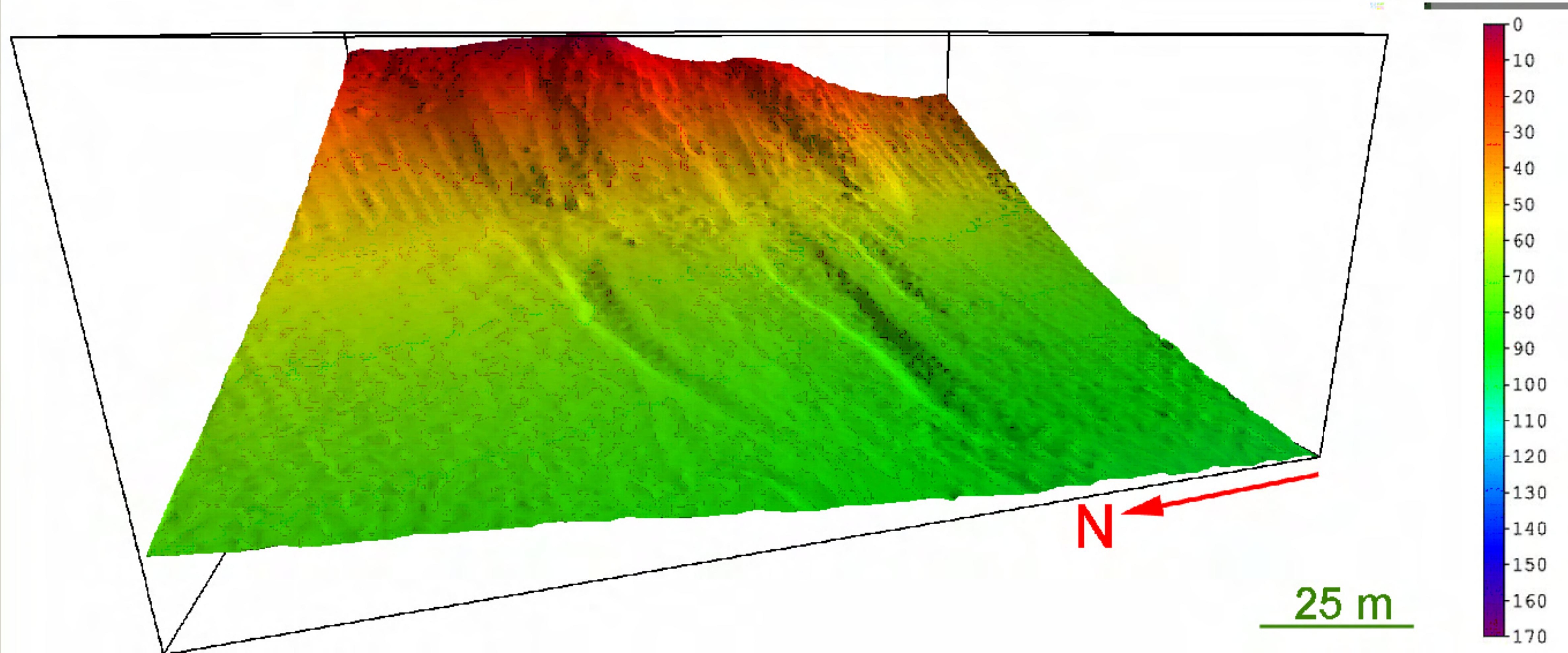




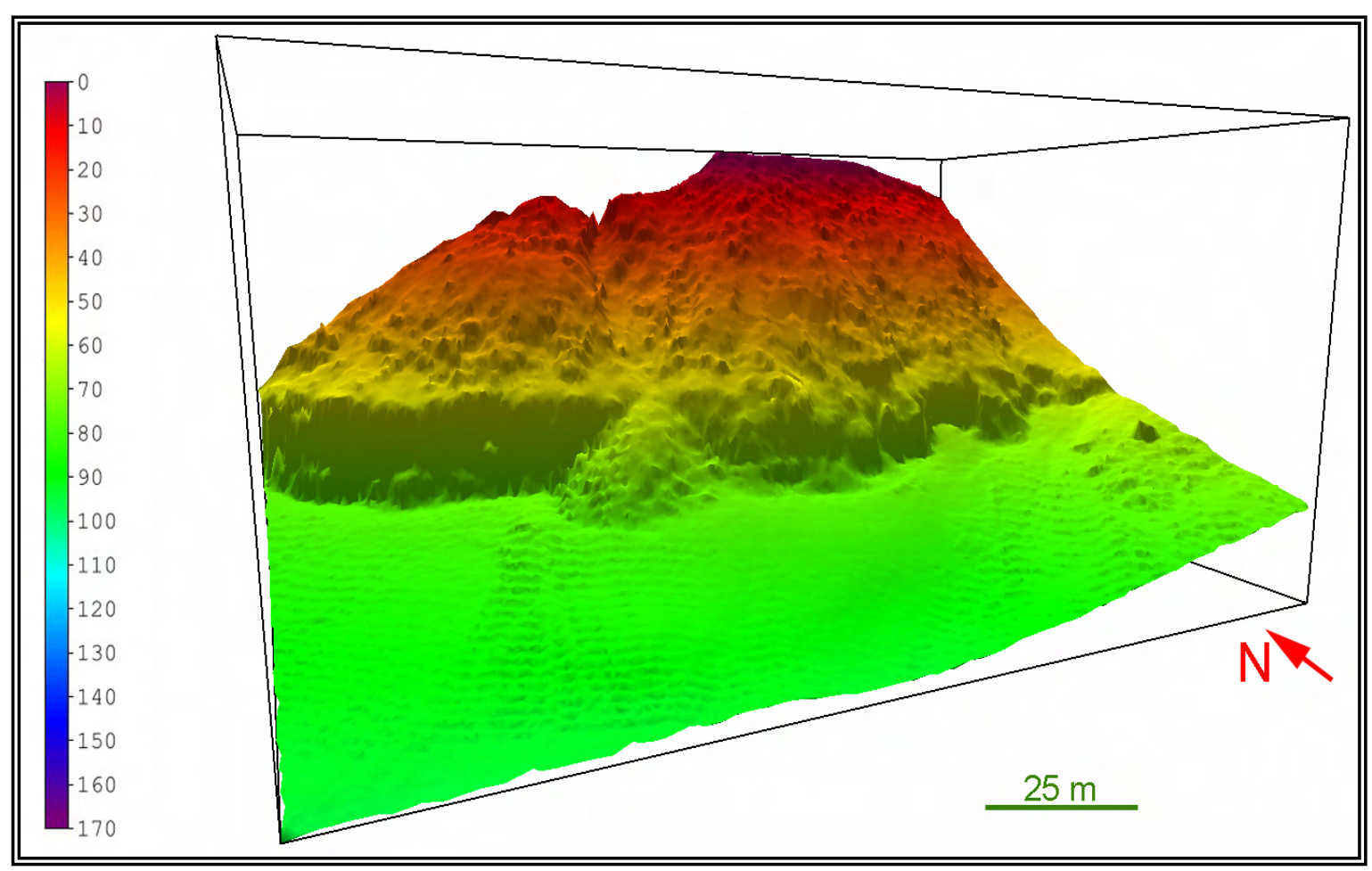

Fig. 9 c 


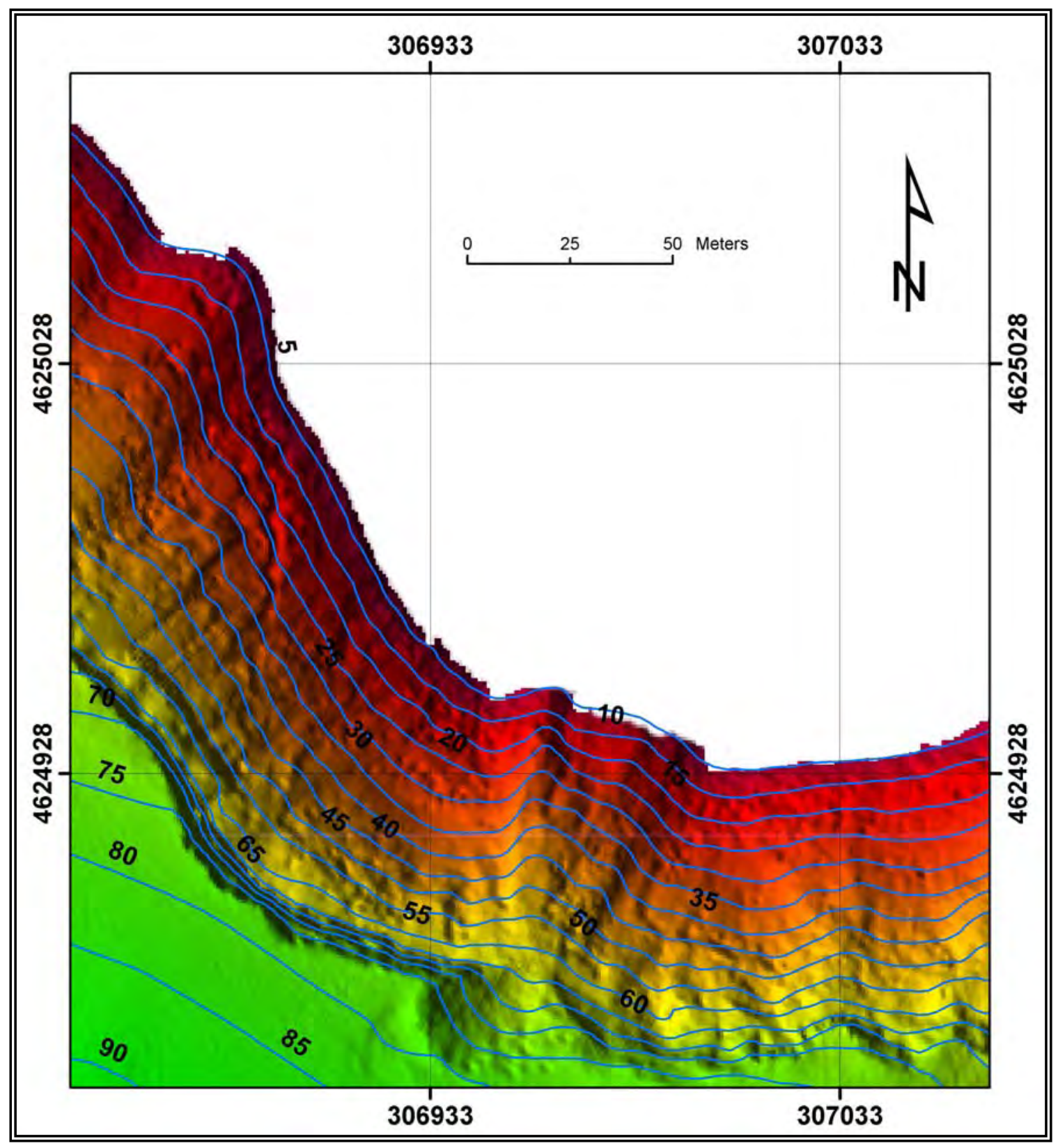

Fig.9 d 